\title{
TO MAKE A CAREER IN KITCHEN DEPARTMENT: IS REALLY THAT A DESIRABLE CAREER PLAN FOR TOURISM STUDENTS?
}

\author{
MUTFAK DEPARTMANINDA KARIYYER YAPMAK: TURIZM ÖĞRENCILERİ ICCIIN \\ GERÇEKTEN ARZU EDİLEN BİR KARIYYR PLANI MI?
}

\author{
Emine KESKİN ${ }^{1}$ - Ömer Akgün TEKİN ${ }^{2}$
}

\begin{abstract}
Nowadays, direct food and beverage-themed tourism types such as food tourism, culinary tourism, gastronomy tourism, and wine tourism are emerging. As a result of these developments, the kitchen has become a strategic competitive area for destinations. In order to become more successful in the field of kitchen, it is also necessary to invest to the education opportunities in this area. The importance of the kitchen in terms of destination, tourism sector and guests, and the attitudes of the students towards the career in the kitchen are also regarded as important. This study aims to examine the attitudes of the students studying at the tourism education towards the kitchen department. The population of the research involves students who studying tourism at a private university in Istanbul, Turkey. Quantitative research methods were used, and data were collected from 282 students using random sampling technique. As a result of the research, it was determined that the students have positive attitudes towards the kitchen department. On the other hand, it was found out that these attitudes of the students differ significantly in terms of their demographic characteristics and personal features.
\end{abstract}

Keywords: Kitchen, Gastronomy, Tourism Students, Kitchen Department, Kitchen Career.

\section{$\ddot{\mathbf{O} z}$}

Günümüzde, yiyecek turizmi, mutfak turizmi, gastronomi turizmi ve şarap turizmi gibi doğrudan yiyecek ve içecek temalı turizm türleri ortaya çıkmaktadır. Bu gelişmelerin sonucu olarak mutfak destinasyonlar için stratejik bir rekabet alanı haline gelmiştir. Mutfak alanında başarılı olabilmek için bu alandaki eğitim olanaklarına yatırım yapmak da gereklidir. Destinasyonlar, turizm sektörü ve misafirler açısından mutfağın önemi olduğu kadar, öğrencilerin mutfakta kariyere yönelik tutumları da önemlidir. Bu çalışma, turizm eğitimi alan öğrencilerin Mutfak departmanına yönelik tutumlarını incelemeyi amaçlamaktadır. Araştırmanın örneklemini Türkiye İstanbul ilinde özel bir üniversitede turizm eğitimi alan öğrenciler oluşturmaktadır. Araştırmada nicel araştırma yöntemleri kullanılmış ve veriler rastgele örnekleme tekniği kullanılarak 282 öğrenciden toplanmıştır. Araştırma sonucunda, öğrencilerin Mutfak departmanına karşı olumlu tutumlar beslediği tespit edilmiştir. Diğer taraftan, öğrencilerin bu tutumlarının demografik özelliklerine göre farklılıklar gösterdiği tespit edilmiştir.

Anahtar Kelimeler: Mutfak, Gastronomi, Turizm Öğrencileri, Mutfak Departmanı, Mutfak Kariyeri

\footnotetext{
${ }^{1}$ Nişantaşı University Vocational School of Higher Education, Department of Culinary, eminekeskin3219@gmail.com, Orcid: 0000-0002-2338-4794

${ }^{2}$ Akdeniz University Manavgat Tourism Faculty, dr.omerakguntekin@ gmail.com, Orcid: 0000-0002-4612-2316 


\section{Introduction}

Food and beverages, which are among the main elements of both tourism industry and hospitality businesses, do not only relieve physiological needs but also affect the individuals' increasing motivation to travel as a culture representative. Thus, Albayrak (2013, p. 5051) stated that culture consists of many elements such as traditions and habits that distinguish societies from each other and that the kitchen culture of societies is among these elements. She further defined the kitchen culture as "a society's diet, the food and beverages that provide the nutrition of that society, the way these foods and beverages are obtained and stored, and the tools, equipment and techniques used to prepare this food and beverages in the kitchen management".

Although food-related tourism activities are expressed in different concepts such as "food tourism", "culinary tourism", and "gastronomy tourism", these concepts have the same meaning (Karim and Chi, 2010, p. 532). Today, kitchen products, which allow a tourism movement in their own right, have a special importance for the tourism sector. Today, kitchen products which lead to a tourism movement in their own right have a special importance for the tourism sector. As a matter of fact, while the kitchen is one of the most important guest satisfaction factors in all types of tourism, food and beverage products and services are the basic satisfaction factor in kitchen-based tourism movements. The destinations that became aware of this fact show different sensitivity to culinary education. It is also possible to observe this sensitivity in the Turkish education system. At present, specific education programs about kitchen in Turkey differ from high school level to post-graduate level. In higher education level, there are two-year and four-year departments such as "Culinary", "Gastronomy and Culinary Arts", and "Food and Beverage Administration". In fact, postgraduate programs are available directly under the name of "Gastronomy and Culinary Arts" and it is seen that post-graduate theses are written in this field. However, the attitudes of students who are educated in this field towards pursuing a career in kitchen field are also important as much as the significance of kitchen culture for the tourism sector and tourists. In this study, the attitudes of the students currently studying in higher education departments, which already provide education in kitchen-related subjects, were examined in the context of their demographic characteristics and personal characteristics. And at the end of the analyses, some statistically significant outputs is founded.

\section{Conceptual Framework}

Different studies in the literature (Aktaş and Özdemir, 2012, p. 3; Çakır, 2010, p. 4; Ignatov and Smith, 2006, p. 238; P1rnar, 2015, p. 35) show that the concept of the kitchen is expressed in various ways. On the other hand, the concept of gastronomy, which is encountered in the kitchen literature, consists of the words "gastros" and "nomos" in Greek and translated into Turkish as "stomach" and "law, rules", expressing healthy, tasty and well prepared dishes as well as a branch of science and art related to setting a table (Tez, 2018, p. 9). The concept of "culinary" which is a term commonly used in gastronomy science that defines the food, food products and food preparation methods of a country or region points to the unique kitchen of that geography (Kivela and Crotts, 2006, p. 355). Another concept frequently encountered in the kitchen literature is "kitchen" and it was evaluated as two parts involving science and arts by Tendret (1825-1896). While this "kitchen" concept is expressed as the realization of the culinary ideas in a good and beautiful way by realizing the truth from the artistic point of view, it is considered as a concept related to chemistry, physics and natural history from a scientific point of view (Hegarty and Antun, 2007, p. 2). In summary, the physical place where the dishes are cooked, the approach of geographies and cultures to 
food and beverages and an artistic field can be expressed with the concept of the kitchen (including kitchen and culinary).

The recognition of eating and drinking habits of societies is one of the elements that explain both the way of life and the level of development of societies, as well as the cultural structure of the kitchen as a whole (Dere Yağar, 2012, p. 4). Thus, Shenoy (2005, p. 11) also states that food is not only a biological behavior, but also a source of taste, as well as a cultural resource that helps increase in the cultural capital thanks to tourists participating in food tourism. Culture tourism is therefore not limited to visiting museums, historical sites or galleries of art; it also includes cooking experiences of kitchen, gastronomy and culinary. Accordingly, the phenomenon of culinary tourism develops as a new form of cultural experience in almost every part of the world (Yun, Hennessey, and MacDonald, 2011, p. 1).

Wolf (2002) describes culinary tourism as a journey for the entertainment and search of prepared foods and beverages, while Long (2004) states that societies have a way of participating in the food culture, including, but not limited to, the preparation, presentation and consumption of food (as cited in: Smith and Costello, 2008, pp. 99-100). Therefore, it can be suggested that culinary tourism involves food and eating activities that individuals experience during their travels (Karim and Chi, 2010, p. 533).

Having reviewed the literature, it was seen that culinary as an alternative type of tourism (Eren, 2011, pp. 39-122) had effects on destination preferences (Göker, 2011, pp. 6491; Zağralı and Akbaba, 2015, pp. 97-103), travel motivations (Sânchez-Canizares and Lôpez-Guzmân, 2012, pp. 234-243; Toksöz and Aras, 2016, pp. 174-184), and tourism destination marketing (Jalis, Che and Markwell, 2014, pp. 104-109).

Food and drink as a vital necessity continue to be important during tourism activities. In the literature, there are previous studies conducted on the contribution of the kitchen to destination, the preferences and the level of satisfaction of tourists for destination and hospitality businesses (Birdir and Akgöl, 2012; Brokaj, 2014; Galvez et al., 2017; Güzel Şahin and Ünver, 2015; Jimenez-Beltran, Lopez-Guzman and Cruz, 2016; Lopez-Guzman et al., 2018; Şengül and Türkay, 2016). Countries that realize the importance of the kitchen in guest satisfaction and destination development also invest in the training opportunities in this field. Turkey is one of the investing countries in kitchen. Today in Turkey, kitchen education in the high school level starts at the Tourism and Hotel Management High Schools, Vocational and Technical High Schools, and Cookery High Schools. In higher education level, there are Culinary, Gastronomy and Culinary Arts, Food and Beverage Services/Management, and many other tourism-related programs in associate, undergraduate, and graduate levels (Table 1). 
Table1: The Structure of Gastronomy Education in Turkey

\begin{tabular}{|c|c|c|}
\hline Level & School & Outcome \\
\hline \multirow[b]{2}{*}{$\begin{array}{l}\text { Vocational } \\
\text { training }\end{array}$} & Private culinary courses & \multirow{2}{*}{$\begin{array}{c}\text { Certificate / } \\
\text { Participation } \\
\text { document }\end{array}$} \\
\hline & $\begin{array}{c}\text { Public culinary courses (served by municipalities and } \\
\text { ISSUR }^{3} \text { ) }\end{array}$ & \\
\hline \multirow{3}{*}{$\begin{array}{l}\text { Secondary school level } \\
\text { (High schools) }\end{array}$} & "Vocational tourism and hotel & \multirow{3}{*}{$\begin{array}{l}\text { High school } \\
\text { Diploma }\end{array}$} \\
\hline & Culinary & \\
\hline & Technical and vocational & \\
\hline \multirow{3}{*}{$\begin{array}{c}\text { Pre-undergraduate } \\
\text { level } \\
\text { (Colleges) }\end{array}$} & Tourism and hotel managemet & \multirow{3}{*}{$\begin{array}{c}\text { Pre- } \\
\text { undergraduate } \\
\text { Diploma }\end{array}$} \\
\hline & Culinary & \\
\hline & Food and beverage services & \\
\hline \multirow{4}{*}{$\begin{array}{c}\text { Undergraduate level } \\
\text { (Faculties) }\end{array}$} & Gastronomy and culinary arts program & \multirow{4}{*}{$\begin{array}{c}\text { Bachelors' degree } \\
\text { Diploma }\end{array}$} \\
\hline & Food and beverage management program & \\
\hline & Tourism and hotel administration program & \\
\hline & Hotel administration program & \\
\hline \multirow{3}{*}{$\begin{array}{l}\text { Postgraduate level } \\
\text { (Social sciences } \\
\text { institutes) }\end{array}$} & Gastronomy and culinary arts program & $\begin{array}{l}\text { M. sc/M.a.Degree } \\
\text { Diploma }\end{array}$ \\
\hline & Tourism and hotel administration program & $\begin{array}{l}\text { M. sc/M.a.Degree } \\
\text { Diploma }\end{array}$ \\
\hline & Tourism and hotel administration program & $\begin{array}{l}\text { Ph.D. degree } \\
\text { Diploma }\end{array}$ \\
\hline
\end{tabular}

The attitudes of the students towards pursuing a career in the kitchen area are as important as the place of kitchen in the tourism industry, destination and guests, and the educational opportunities in this field. In the literature, it is possible to access various studies related to the attitudes of tourism students towards the kitchen field. Some of these studies and the findings are reported as follows:

In the study carried out by Kurnaz, Kurnaz and Kılıç (2014), it was aimed to determine the attitudes of the students who study at Culinary Education at associate degree level. As a result of the study, it was determined that the majority of the students had positive thoughts about the culinary profession. In a part of the study conducted by Çavuş and Kaya (2015), the departmental distributions of students where they wanted to work were determined according to the departments they study. Based on this, only $6 \%$ of the students studying in the departments of Tourism and Hotel Administration, Food and Beverage Administration, Travel Agency and Tour Guiding were found to have a career tendency in the kitchen. Moreover, it was found out that all of the students who wanted to have a career in the kitchen field studied at Food and Beverage Administration Department. Only 17\% of the students studying in this department do not want to work in the kitchen department. In the study conducted by Tekin and Deniz (2015), it was determined that the students ' attitudes towards this department were moderately positive. Among all of the food and beverage departments, the most positive student attitude was found to be in the Culinary Department. In addition, Tekin and Çidem (2017) examined the attitudes of the students towards a career in the kitchen department. As a result of the study, it was found out that the students had a positive attitude towards the career in the kitchen. In that study, it was determined that students who got introduced with the field of tourism from high school, gained experience in this field, chose the department they currently study on purpose, and intended to continue their career in this field had more positive attitudes towards a career in the kitchen. Akoglu et al., (2017) examined in their study the attitudes of Gastronomy and Culinary Arts students

\footnotetext{
${ }^{3}$ Turkish Employment Agency.
} 
towards working in the sector. As a result of the study, it was indicated that the students wanted to work in the kitchen after graduation or to teach about the field. Besides, they also underlined that working conditions in the kitchen are tiring, stressful and require a long shift. Deveci et al., (2017) studied the attitudes of Gastronomy and Culinary Arts students towards the kitchen department. As a result of the research, it was determined that students had positive attitudes towards the kitchen department. It was also suggested in the study that the students in the 18-20 age group and second graders had more positive attitudes towards the kitchen department. In the study conducted by Kutuk1z, Akyürek and Özdemir (2018), the attitudes of high school students towards a career in the kitchen department were investigated. The results of the research determined that the students' attitudes towards a career in the kitchen department were positive.

The limited previous literature on the subject resulted in insufficient knowledge about the attitudes of the students towards the kitchen department. In this study, it is aimed to fill in this gap and to contribute to the literature and tourism industry by making in-depth analyses of the attitudes of the students towards the kitchen department in the context of various demographic characteristics and personal characteristics.

\section{Methodology}

Food and beverage sector is an important part of the tourism industry. Therefore, the kitchen, which is a representative of culture, is one of the indispensable elements of the tourism industry. In this study, it is aimed to measure the attitudes of the students studying at the associate degree of Culinary and Tourism and Hotel Management and the undergraduate level of Gastronomy and Culinary Arts programs towards the kitchen department. In addition, the sub-objective of this study was determined to investigate the differences between the attitudes of the students towards the kitchen department and their demographic characteristics and personal characteristics. Thus, the following hypotheses were tested in the study:

$H_{1}$ : There is a significant difference between the attitudes of the students towards the kitchen department and their gender.

$\mathrm{H}_{2}$ : There is a significant difference between the attitudes of the students towards the kitchen department and the type of academic program they study.

$H_{3}$ : There is a significant difference between the attitudes of the students towards the kitchen department and the grade they are in.

$\mathrm{H}_{4}$ : There is a significant difference between the attitudes of the students towards the kitchen department and previous experience in the tourism sector.

$\mathrm{H}_{5}$ : There is a significant difference between the attitudes of the students towards the kitchen department and the departments where they work most in the sector.

$H_{6}$ : There is a significant difference between the attitudes of the students towards the kitchen department and their age.

$H_{7}$ : There is a significant difference between the attitudes of the students towards the kitchen department and the type of high school they graduated from.

In this study, descriptive research method of quantitative research methods is used. Descriptive research includes the studies carried out by the researcher in relation to a sampling to identify phenomena, relationships, situations, and events (Thomlison, 2001; Rubin and Bobbie, 2008: as cited in: Tripodi and Bender, 2010, p. 120).

The research population consists of students who are studying at Nişantaşı University in Istanbul in the associate degree level in Culinary and Tourism and Hotel Management 
programs and in the undergraduate level in Gastronomy and Culinary Arts program. The research was conducted on the population of 581 students studying at the relevant programs in the 2017-2018 academic year spring semester. According to Can (2013, p. 30), a sample size that can quantitatively represent the research population in this size with a 5\% sampling error and $95 \%$ reliability level must at least include 185 participants. In the study, it was initially planned to collect data via "complete inventory" method, but later it was determined that due to timewise and economic reasons it would not be possible to use this method, hence sampling was conducted. Convenience sampling technique of improbable sampling methods was used in this study. This technique, which is also named as opportunity sampling or accidental sampling, recommends access to individuals who are easy to contact, readily available, and eligible (Bhattacherjee, 2012, p. 69).

345 questionnaire forms were distributed to the students throughout the study. However, because some of the students did not return the forms and 58 of the returned questionnaires were found to be filled in an incorrect way, the research analyses were conducted with the data from 282 students. In the analysis of the data, SPSS 21.0 (Statistical Package for the Social Sciences) software was used.

Questionnaire technique was used in the data collection procedure. The data collection tool involves demographic characteristics and personal features (DCPF) form and The Scale of Undergraduate Tourism Students Attitudes' toward Cuisine Department (TSACD). The DCPF form is composed of 8 closed-ended questions prepared by the researchers. On the other hand, TSACD Scale was developed by Tekin and Çidem (2015) and it has 5 factors and 28 questions. TSACD Scale was designed based on five-point Likert system (1: strongly disagree, 3: moderately agree, 5: strongly agree). The reliability coefficient of TSACD Scale is (Cronbachs' alpha) 0,946, and it was reviewed by academics, professionals in the sector and linguists in terms of content and language validity. The sample adequacy and construct validity values of this scale was examined with Kaiser-Meyer-Olkin (KMO) test and Bartlett's test of sphericity, and its factor structure was measured with exploratory factor analysis (Tekin and Çidem, 2015, pp. 978-983).

\section{Findings}

\subsection{Demographic Characteristics and Personal Features}

Information about the demographic characteristics of the students participating in the research is presented in Table 2. 
Table 2: Demographic Characteristics and Personal Features of the Sample

\begin{tabular}{|c|c|c|c|}
\hline & & $\mathbf{n}$ & $\%$ \\
\hline \multirow{2}{*}{ Gender } & Female & 154 & 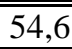 \\
\hline & Male & 128 & $4 \overline{45,4}$ \\
\hline \multirow{2}{*}{ Age } & $\leq 20$ & 113 & 40,1 \\
\hline & $\geq 21$ & 169 & 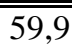 \\
\hline \multirow{3}{*}{ Academic programme } & Culinary & 109 & 38,7 \\
\hline & Tourism and Hotel Management & 53 & 18,8 \\
\hline & Gastronomy and Culinary Arts & 120 & 42,6 \\
\hline \multirow{4}{*}{ Grade } & First grade & 77 & 27,3 \\
\hline & Second grade & 134 & $4 \overline{47,5}$ \\
\hline & Third grade & 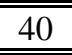 & 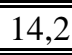 \\
\hline & Fourth grade & 31 & 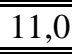 \\
\hline \multirow{2}{*}{ What type of high school did you graduate? } & High school associated with hospitality & 94 & 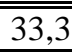 \\
\hline & Other high schools & 188 & 66,7 \\
\hline \multirow{2}{*}{ Have you ever worked in tourism industry? } & Yes & 224 & $\overline{79,4}$ \\
\hline & No & 58 & 20,6 \\
\hline \multirow{3}{*}{$\begin{array}{l}\text { Departments worked with the longest work } \\
\text { experience }\end{array}$} & Kitchen/Cuisine & 140 & 49,6 \\
\hline & Restaurant and bar & 59 & 20,9 \\
\hline & Other (Front office, Accounting et al.) & 83 & 29,4 \\
\hline
\end{tabular}

When the demographic characteristics of the students were examined, it was seen that $55 \%$ of them were female students and $60 \%$ of them were 21 years and above. In terms of the students' other criterion, $43 \%$ of them are in Gastronomy and Culinary Arts program and $48 \%$ of them are in second grade. Regarding the type of high school the participants graduated from, it was found out that $67 \%$ of participants graduated from a high school that is not related to tourism. It was also indicated that $79 \%$ of the students who participated in the study had experience in the tourism sector, and $50 \%$ of them had experience in the kitchen department.

\subsection{Findings of Scales and Hypotheses}

Before the analysis of the hypothesis of the research, various analyzes were performed on the reliability of TCASD scale. As a result of the analysis, reliability coefficient of TCASD scale was found to be a highly reliable (Ural and Kılıç, 2011, p. 290) at a level of (Cronbach's Alpha) 0,897 $(0,80<p<1)$. After an in-depth analysis of the scale, there was no item which significantly reduced the overall reliability level of the scale, therefore no items were removed from the scale.

After the reliability analysis, the scale was subjected to Kaiser-Meyer-Olkin (KMO:, 855; KMO> 0,50) and Bartlett's test of sphericity in terms of their suitability for exploratory factor analysis (EFA), and the scale's compliance with factor analysis $(\mathrm{p}<0.05 ; \mathrm{p}:, 000)$ were determined. After the determination of the factor analysis of TCASD scale, it was subjected to exploratory factor analysis with Varimax rotation EFA without any restriction in the number of factors. As a result of this analysis, it was found out that some items had low communalities while some other items were categorized under the insignificant factors and formed 7 different factors. Items with low factor loadings and items that were categorized under the insignificant factors were removed from the scale, and factor analysis was renewed. In the final stage, it was determined that 18 items remaining in the scale were significantly 
grouped under 4 factors (Abilities, Environmental Impact, Importance of Cuisine Department, Nature of Work) and total variance explained value was 61,278 (p>0,50).

After EFA, the remaining items in the scale were again subjected to reliability analysis and it was found that the coefficient of general reliability of the scale was (Cronbach's Alpha) 0,865 . As a result of the reliability test based on the factors, it was indicated that reliability coefficient value of Abilities factor was 0,933, Environmental impact factor was 0,824, Importance of kitchen department factor was 0,678, and Nature of work factor was 0,697. Before continuing with the other analysis, mean values of attitudes of the students towards the kitchen department were examined based on the factors, and the results are shown in Table 3.

Table 3: Descriptive Statistics of Attitudes of the Students towards the Kitchen Department

\begin{tabular}{l|c}
\hline \hline \multicolumn{1}{c|}{ Factors } & Mean \\
\hline \hline Abilities (A) & 4,02 \\
\hline \hline Environmental impact (EI) & 3,86 \\
\hline \hline Importance of kitchen department (ICD) & 4,21 \\
\hline \hline Nature of work (NW) & 3,62 \\
\hline \hline General attitudes toward kitchen department & $\mathbf{3 , 9 6}$ \\
\hline \hline
\end{tabular}

When the general attitudes and factor-based attitudes of students towards the kitchen department were examined, it was indicated that the most positive attitudes of students were found to be in importance of kitchen department $(\overline{\mathrm{X}}: 4,21)$ and abilities $(\overline{\mathrm{X}}: 4,02)$ factors. These are followed by environmental impact $(\overline{\mathrm{X}}: 3,86)$ and finally by nature of work $(\overline{\mathrm{X}}: 3,62)$ factors. In a general sense, it was seen that the attitudes of students towards the kitchen department were ultimately positive ( $\overline{\mathrm{X}}: 3,96)$. These findings clearly show that the attitudes of the students towards the kitchen department are more positive than the mean score $(\overline{\mathrm{X}}>3,50)$ both in terms of scale as a whole and for each factor.

Table 4: Normal Distribution Analysis of Factors

\begin{tabular}{l|c|c}
\hline \multicolumn{1}{c|}{ F a c t o r s } & p & Z \\
\hline \hline Abilities (A) & 0,016 & 1,314 \\
\hline \hline Environmental impact (EI) & 0,014 & 1,571 \\
\hline \hline Importance of kitchen department (ICD) & 0,000 & 2,655 \\
\hline \hline Nature of work (NW) & 0,000 & 2,411 \\
\hline \hline
\end{tabular}

In order to determine which type of test to use to analyze the research hypotheses, the items grouped under four factors were tested using the Kolmogorov-Smirnov method for normal distribution analysis. As a result of the test, the factors did not show a normal distribution ( $\mathrm{A} \mathrm{p}_{1}, \mathrm{EI} \mathrm{p}_{2}, \mathrm{ICD} \mathrm{p}_{3}, \mathrm{NW} \mathrm{p}_{4}<0,05-$ Table4) and accordingly non-parametric methods were used to test the hypotheses of the study. Mann-Whitney U and Kruskal-Wallis $\mathrm{H}$ Tests of non-parametric tests were preferred in order to test the hypotheses prepared in accordance with the objectives of the study. The significant findings obtained from the testing of the hypotheses presented in Table 1 are presented in Table 5. 
Table 5: Analysis of Hypotheses

\begin{tabular}{|c|c|c|c|c|}
\hline $\begin{array}{l}\text { Attitudes towards to kitchen department \& } \\
\text { Gender }\end{array}$ & Gender & $\begin{array}{l}\text { Mean } \\
\text { Rank }\end{array}$ & $\begin{array}{c}\text { Mann- } \\
\text { Whitney U } \\
\text { Value } \\
\end{array}$ & Sig. \\
\hline \multirow{2}{*}{ Abilities } & Female & 153,07 & \multirow{2}{*}{8074,500} & \multirow{2}{*}{,008 } \\
\hline & Male & 127,58 & & \\
\hline $\begin{array}{l}\text { Attitudes towards to kitchen department \& } \\
\text { Academic programme }\end{array}$ & Academic programme & $\begin{array}{l}\text { Mean } \\
\text { Rank }\end{array}$ & $\begin{array}{c}\text { Chi-Square } \\
\text { Value }\end{array}$ & Sig. \\
\hline \multirow{3}{*}{ Abilities } & Culinary & 14143,83 & \multirow{3}{*}{9,747} & \multirow{3}{*}{,008 } \\
\hline & $\begin{array}{l}\text { Tourism and Hotel } \\
\text { Management } \\
\end{array}$ & 111,50 & & \\
\hline & Gastronomy and Culinary Arts & 152,64 & & \\
\hline \multirow{3}{*}{ Environmental impact } & \begin{tabular}{|l} 
Culinary \\
\end{tabular} & 125,91 & \multirow{3}{*}{9,850} & \multirow{3}{*}{,007 } \\
\hline & $\begin{array}{l}\text { Tourism and Hotel } \\
\text { Management }\end{array}$ & 134,51 & & \\
\hline & Gastronomy and Culinary Arts & 158,75 & & \\
\hline \multirow{3}{*}{ Importance of kitchen department } & Culinary & 125,93 & \multirow{3}{*}{6,712} & \multirow{3}{*}{,035 } \\
\hline & $\begin{array}{l}\text { Tourism and Hotel } \\
\text { Management }\end{array}$ & 147,60 & & \\
\hline & Gastronomy and CulinaryArts & 152,95 & & \\
\hline $\begin{array}{l}\text { Attitudes towards to kitchen department \& } \\
\text { Grade }\end{array}$ & Grade & $\begin{array}{l}\text { Mean } \\
\text { Rank }\end{array}$ & $\begin{array}{l}\text { Chi-Square } \\
\text { Value }\end{array}$ & Sig. \\
\hline \multirow{4}{*}{ Abilities } & First grade & 155,40 & \multirow{4}{*}{9,877} & \multirow{4}{*}{020} \\
\hline & Second grade & 12127,42 & & \\
\hline & Third grade & 141,01 & & \\
\hline & Fourth grade & 168,48 & & \\
\hline \multirow{4}{*}{ Environmental impact } & First grade & 153,10 & \multirow{4}{*}{30,853} & \multirow{4}{*}{, 000} \\
\hline & Second grade & 116,51 & & \\
\hline & Third grade & 192,28 & & \\
\hline & Fourth grade & 155,19 & & \\
\hline \multirow{4}{*}{ Importance of kitchen department } & First grade & 137,23 & \multirow{4}{*}{8,176} & \multirow{4}{*}{,043 } \\
\hline & Second grade & 131,84 & & \\
\hline & Third grade & 169,78 & & \\
\hline & Fourth grade & 10157,40 & & \\
\hline $\begin{array}{l}\text { Attitudes towards to kitchen department \& } \\
\text { Tourism experience }\end{array}$ & Tourism experience & $\begin{array}{l}\text { Mean } \\
\text { Rank }\end{array}$ & $\begin{array}{c}\text { Mann- } \\
\text { Whitney U } \\
\text { Value } \\
\end{array}$ & Sig. \\
\hline \multirow{2}{*}{ Abilities } & Yes & 148,67 & \multirow{2}{*}{4889,000} & \multirow{2}{*}{, 003} \\
\hline & No & 1113,79 & & \\
\hline \multirow{2}{*}{ Nature of work } & Yes & 14147,82 & \multirow{2}{*}{5081,000} & \multirow{2}{*}{,010 } \\
\hline & No & 117,10 & & \\
\hline $\begin{array}{l}\text { Attitudes towards to kitchen department \& } \\
\text { Departments worked with the longest } \\
\text { experience }\end{array}$ & Departments & $\begin{array}{l}\text { Mean } \\
\text { Rank }\end{array}$ & $\begin{array}{l}\text { Chi-Square } \\
\text { Value }\end{array}$ & Sig. \\
\hline \multirow{3}{*}{ Abilities } & Kitchen/ Cuisine & 161,98 & & \\
\hline & Restaurant and bar & 156,86 & 37685 & 000 \\
\hline & $\begin{array}{l}\text { Other (Front office, } \\
\text { Accounting et al.) }\end{array}$ & 96,03 & & \\
\hline & Kitchen/ Cuisine & 157,68 & & \\
\hline Nature of work & Restaurant and bar & 10164,14 & 33822 & 000 \\
\hline & $\begin{array}{l}\text { Other (Front office, } \\
\text { Accounting et al.) }\end{array}$ & 98,11 & & \\
\hline
\end{tabular}

In Table 5, whether the attitudes of students towards the kitchen department differed statistically and significantly in terms of their gender was analyzed through the MannWhitney U Test. As a result, it was found out that the attitudes of students towards abilities 
factor varied significantly according to their gender ( $p: 0,008 ; p \leq 0,05)$, and the attitudes of the female students towards the kitchen department were more positive.

When the attitudes of students towards the kitchen department were examined in terms of the academic program, Gastronomy and Culinary Arts students had more positive attitudes in the factors of abilities, environmental impact, and importance of kitchen department (Table 4).

When the attitudes of students towards the kitchen department were examined in terms of their grades, it was seen that fourth grade students had more positive attitudes in the abilities factor while third grade students had more positive attitudes in the environmental impact and importance of kitchen department factors (Table 5).

As presented in Table 4, it is seen that there is a statistically significant difference between the attitudes of students towards the kitchen department and their experiences in the tourism sector. It is also indicated that the attitudes of the students who have experience in the tourism sector are more positive in the abilities and nature of work factors.

When the difference between the attitudes of students towards kitchen department and the department they work most in the sector are examined, the attitudes of students with the experience in working in the kitchen department in the abilities factor were found to be more positive than the experiences of students in the other departments. In the nature of work factor, it was extraordinary to observe that the students working mainly in the restaurant and bar department had a more positive attitude.

In the analyses carried out to test hypotheses, it was determined that the attitudes of students towards the kitchen department did not change significantly according to age and the type of high school they graduated from. Therefore, related hypotheses $\left(\mathrm{H}_{6}\right.$ and $\left.\mathrm{H}_{7}\right)$ were rejected and the other hypotheses $\mathrm{H}_{1}, \mathrm{H}_{2}, \mathrm{H}_{3}, \mathrm{H}_{4}$ and $\mathrm{H}_{5}$ were accepted.

\section{Discussion}

When the demographic characteristics and personal features of the students were examined, it was seen that more than half of the students were female $(55 \%)$ and 21 years and above $(60 \%)$. Based on academic programs that participants, it was determined that $42.6 \%$ of them studied at Gastronomy and Culinary Arts, 38.7\% at Culinary, and $18.8 \%$ at Tourism and Hotel Management programs. Moreover, it was determined that $48 \%$ of the participants were second grade students while $67 \%$ graduated from a high school type which is not related to tourism. $79 \%$ of the students who participated in the study stated that they had experience in the tourism sector while 50\% expressed that they had experience in the kitchen department. When the demographic characteristics and personal features of the students are examined in general terms, it can be said that there is a balanced distribution in terms of participants' gender, age group, and experience in tourism industry. The fact that the majority of the students have experience in the tourism sector and half of them have experience in the kitchen department suggests that they have improved themselves regarding the programs they are studying. Accordingly, having experience in the same field of education, creates a positive condition in terms of the employment of qualified labor force in the tourism industry.

One of the most significant findings obtained as a result of the analysis in the research is that the students generally and on the basis of factors have a very positive attitude towards the kitchen department. Students find the kitchen department quite important $\left(\overline{\mathrm{X}}_{\mathrm{ICD}}\right.$ : 4,21) and show a similar level of positive attitude towards their individual skills $\left(\overline{\mathrm{X}}_{\mathrm{A}}\right.$ : 4,02). Additionally, the fact that students have positive attitudes towards the kitchen department with respect to various environmental impact $\left(\overline{\mathrm{X}}_{\mathrm{EI}}: 3,86\right)$ and nature of work $\left(\overline{\mathrm{X}}_{\mathrm{NW}}\right.$ : 3,62) can 
be regarded as an ultimately positive situation with regards to responding to the needs of the qualified workforce in the tourism sector. Moreover, these positive attitudes suggest that the kitchen staff of the future will develop positive attitudes towards the profession and practice their profession as it should and efficiently. In the study carried out by Tekin and Çidem (2017, p. 41), the fact students showed positive attitudes both in the kitchen department in general and factors supports the findings of this research.

In this study, 7 hypotheses were suggested to examine the attitudes of the students towards the kitchen department, and as a result of the analyses, there was statistically significant difference between the attitudes of the students towards the kitchen department and their gender, academic program, grade, experience in the tourism sector, and the departments where they work most in the sector. According to the findings, female students had more positive attitudes towards the kitchen department than male students in the abilities factor $\left(\mathrm{H}_{1}\right)$. This shows that female students perceive themselves as more skilled in the kitchen than the male. Therefore, it can be inferred that the fact that girls show more tendency to the kitchen as a gender role can be effective in finding such a result. Similarly, Harbalioglu and Unal $(2014$, p. 61) in their study on attitudes towards the culinary profession with the participation of associate students found out that the attitudes towards the culinary profession differ significantly according to gender variables.

It was determined that there was a statistically significant difference between the attitudes of the students towards the kitchen department and the academic program (H2). It was also found out that Gastronomy and Culinary Arts students had more positive attitudes in the factors of abilities, environmental impact, and importance of the kitchen department. This leads to the inference that Gastronomy and Culinary Arts students are more aware of their individual abilities than the students in the other programs, and it can be the result of taking more practical culinary courses during their education. Moreover, the fact that students' families and close circles see the occupations in the kitchen department as popular occupations than the other departments and support them in finding jobs in this department is considered to cause this result. Lastly, that the students who are studying in an undergraduate program are more conscious and questioning than the students who are studying in associate degree programs is thought to be effective in finding such results. This finding shows similarity with the findings of Tekin and Deniz's (2015, p. 188) research in Tourism and Hotel Management, Culinary, Hospitality Management and Tourism Management programs. According to the results, the attitudes of the students who are studying in the culinary program towards the food and beverage department were positive. This similarity is considered to stem from the fact that these two academic programs are directly related to the kitchen.

As a result of the analysis carried out in line with the $\mathrm{H}_{3}$ hypothesis, it was found out that the attitudes of fourth grade students towards the kitchen department were more positive in the abilities factor. This can lead to the inference that students become more aware of their individual abilities as they draw near graduation by having an intensive education in the practical aspect of the kitchen education and getting experienced in the kitchen departments or tourism sector through internships or willingly. In the environmental impact and importance of kitchen department factors, the attitudes of third grade students were more positive. This result indicates that the courses taken during the academic program and surely their experiences make students become aware of the significance of the kitchen department, and environmental impact (family and close circle) also has effects on their attitudes towards the kitchen department. Thus, Deveci et al. (2017, p. 726) found that there was a statistically significant difference between the attitudes of students towards the kitchen department and grade in the study conducted with first, second, and third grade gastronomy students. 
It was determined that the attitudes of students who have experience in the tourism sector in abilities and nature of work factors were more positive $\left(\mathrm{H}_{4}\right)$. When the departments that students had experience were examined $\left(\mathrm{H}_{5}\right)$, students who had experience respectively in the kitchen, restaurant and bar departments had higher attitudes. In the nature of work factor, it was observed that students with the experiences respectively in restaurant and bar kitchen departments had more positive attitudes. Accordingly, students who have experience in the tourism sector consider themselves more capable than those who are inexperienced. On the other hand, students who have experience in the kitchen department have a more positive attitude towards the nature of the work in the kitchen. In addition, according to the results, when students have a specific experience in the kitchen or food departments, it is considered that they can understand their individual skills and the quality of the work more easily and therefore have a more positive attitude towards the kitchen department.

\section{Results and Recommendations}

One of the most significant findings obtained as a result of the analysis in the research is related to the students' positive attitude towards the kitchen department in general and on the basis of factors. As a result of the analysis of 7 hypotheses established in the research; it is determined that there is statistically significant difference between students' attitudes towards kitchen department, gender, academic program, grade, experience in the tourism sector, and tourism departments. According to the findings, in the Abilities factor it was seen that the attitudes of the female students towards the kitchen department were more positive than the male students. Gastronomy and Culinary Arts students have a more positive attitude in Abilities, Environmental Impact and Importance of Cuisine Department factors. The attitudes of fourth grade students towards the kitchen department were found to be more positive in the Abilities factor. The attitudes of third grade students were higher in the Environmental Impact and Importance of Cuisine Department factors. Abilities and Nature of work factors show that students with experience in tourism sector have more positive attitudes than students without experience. When the departments in which students have gained experience are examined; in the Abilities factor, students who have experience respectively in the kitchen, restaurant and bar departments had higher attitudes. In the nature of work factor, students who have experience respectively in the restaurant and bar departments had higher attitudes.

The research has several limitations as it is only limited to students studying in the Nişantaşı University Culinary, Tourism and Hotel Management, and Gastronomy and Culinary Arts Programs. The inability of reaching out to all students in these academic programs during the research process is also another limitation of the study. It is also assumed that the students who participated in the study understood the items on the scale correctly and answered them as real as possible.

Since the findings of this study are limited to the sample of the study, it is thought that the application of future research on students studying in different regions and different educational institutions in culinary, gastronomy and culinary arts, and tourism education in undergraduate and associate levels can provide more comprehensive information on the subject.

Some recommendations have been developed in line with the results obtained from the research and the information obtained from the literature. There should be courses on Turkish kitchen in the tourism-related schools and activities for the promotion of Turkish kitchen should be arranged in cooperation with the Ministry of Culture and Tourism. Increasing the promotion of Turkish kitchen will also be useful in the process of creating a Turkish kitchen brand. For Turkey, gastronomy tourism is a very important issue. Therefore, the Ministry of Culture and Tourism, universities, Association of Turkish Travel Agencies (TÜRSAB) and 
the other organizations related to tourism should act together and in a planned manner. Turkey's variety of food cannot be denied, therefore, it is a necessity to carry out activities on food tourism or gastronomy tourism in a sustainable way. The number of graduate theses in the field of gastronomy in Turkey is limited. In order to increase the number of these studies, encouraging programs should be developed and thesis writing should be encouraged in the field of gastronomy.

\section{REFERENCES}

Akoğlu, A., Cansızoğlu, S., Orhan, N., \& Özdemir, Z. (2017). Gastronomi ve mutfak sanatları eğitimi alan öğrencilerin sektörde çalışmaya yönelik bakış açıları. Journal of Tourism and Gastronomy Studies, 5(2), 146-159.

Aktaş, A., \& Özdemir, B. (2012). Otel işletmelerinde mutfak yönetimi. (3. Edition). Ankara: Detay Yayıncilık.

Albayrak, A. (2013). Farklı milletlerden turistlerin Türk mutfağına ilişkin görüşlerinin saptanması üzerine bir çalışma. Journal of Yaşar University, 30 (8), 5049-5063.

Aslan, H., \& Aktaş, N. (2011). Turizm ön lisans öğrencilerinin gastronomi turizmine yönelik tutumları ve gastronomi davranışlarının belirlenmesi. E-Journal of New World Sciences Academy, 6(3), 363-373.

Bhattacherjee, A. (2012). Social science research: principles, methods and practices. Textbook collection, (2. Edition). University of South Florida, USA: Scholar Commons,

Birdir, K., \& Akgöl, Y. (2015). Gastronomi turizmi ve Türkiye'yi ziyaret eden yabanc1 turistlerin gastronomi deneyimlerinin değerlendirilmesi. Işsletme ve İktisat Çalışmaları Dergisi, 3(2), 57-68.

Brokaj, M. (2014). Theimpact of gastronomic offer in choosing tourism destination: Thecase of Albania. Academic Journal of Interdisciplinary Studies, 3(2), 249-258.

Can, A. (2013). SPSS ile bilimsel araştırma sürecinde nicel veri analizi. (1. Edition). Ankara: Pegem Akademi Yayınları.

Çakır, M. (2010). Otel işletmelerinin mutfak bölümünde istihdam edilen personelin ĕgitim sürecinin değerlendirilmesi: İstanbul'daki 5 ylldılı zincir otellere yönelik bir alan araştırmas1. Master thesis, İstanbul University, İstanbul, Turkey.

Çavuş, Ş., \& Kaya, A. (2015). Turizm lisans eğitimi alan öğrencilerin kariyer planları ve turizm sektörüne yönelik tutumu. Manas Journal of Social Studies, 4(5), 101-117.

Çemrek, F. \& Yılmaz, H. (2010). Turizm ve otel işletmeciliği ile aşçıllk programı öğrencilerinin "uygulamalı mutfak dersleri" hakkında tutum ve düşüncelerinin ölçmeye yönelik bir uygulama. Sosyal Bilimler Dergisi, 12(2): 203-220.

Dere Yağar, H. (2012). Antalya mutfak ve yemek kültürü müzesi tasarımı. Master thesis, Akdeniz University, Antalya, Turkey.

Deveci, B., Deveci, B., Karaman, N., \& Aymankuy, Y. (2017). Mutfak departmanına yönelik tutum: Gastronomi ve mutfak sanatları öğrencileri üzerine bir araştırma. Akademik Bakış Dergisi, 64, 717-732.

Eren, D. (2011). Alternatif bir turizm çeşidi olarak mutfak turizminin değerlendirilmesine ilişkin sektör temsilcilerinin görüşlerinin incelenmesi üzerine bir araştırma. Master thesis, Düzce University, Düzce, Turkey. 
Galvez, J. C. P., Lopez-Guzman, T., Buiza, F. C., \& Medina-Viruel, M. J. (2017). Gastronomy as an element of attraction in a tourist destination: Thecase of Lima, Peru. Journal of Ethnic Food, 4(2017), 254-261.

Göker, G. (2011). Destinasyon çekicilik unsuru olarak gastronomi turizmi (Ballkesir ili örneği). Master thesis, Balıkesir University, Balıkesir, Turkey.

Güzel Şahin, G., \& Ünver, G. (2015). Destinasyon pazarlama aracı olarak "gastronomi turizmi: İstanbul'un gastronomi turizmi potansiyeli üzerine bir araştırma. Journal of Tourism and Gastronomy Studies, 3(2), 63-73.

Harbalığlu, M., \& Ünal, İ. (2014). Aşçılık programı öğrencilerinin mesleki tutumlarının belirlenmesi: Ön lisans düzeyinde bir uygulama. Turizm Akademik Dergisi, 1(1), 57-67.

Hegarty, J. A., \& Antun, J. M. (2007). Celebrate culinary science and gastronomic knowledge!.Journal of Culinary Science \& Technology, 5(4): 1-7.

Ignatov, E. \& Smith S. (2006). Segmenting canadian culinary tourists. Current Issues in Tourism, 9(3), 235-255.

Jalis, M., Che, D., \& Markwell, K. (2014). Utilising local cuisine to market Malaysia as a tourist destination. Procedia-Social and Behavioral Sciences, 144, 102-110.

Jimenez-Beltran, F. J., Lopez-Guzman, T., \& Cruz, F. G. S. (2016). Analysis of the relationship between tourism and food culture. Sustainability, 2016(8), 1-10.

Karim, S. A., \& Chi, C. G-Q. (2010). Culinary tourism as a destination attraction: An empirical examination of destinations' foodimage. Journal of Hospitality Marketing and Management, 19(6), 531-555.

Kivela, J., \& Crotts, J. C. (2006). Tourism and gastronomy: Gastronomy's influence on how tourists experience a destination. Journal of Hospitality \& Tourism Research, 30(3): 354-377.

Kurnaz, A., Kurnaz, H. A., \& Kılıç, B. (2014). Önlisans düzeyinde eğitim alan aşçılık programı öğrencilerinin mesleki tutumlarının belirlenmesi. Muğla Sitkl Koçman Üniversitesi Sosyal Bilimler Enstitüsü Dergisi, 32(2004), 41-61.

Kutukız, D., Akyürek, S., \& Özdemir, Ö. (2018). Turizm eğitimi alan ortaöğretim düzeyindeki ögrencilerin mutfak departmanına yönelik tutumlarını belirlemeye yönelik bir araştırma. International Journal of Society Researches, 8(8), 125-146.

Lopez-Guzman, T., Torres Naranjo, M., Perez-Galvez, J. C., \& Carvache Franco, W. (2018). Gastronomic perception and motivation of a touristic destination: Thecity of Quito, Ecuador, 1(21), 61-73.

Özdemir, B. (2001). Otel işletmelerinde mutfak yönetimi ve her şey dahil (all-inclusive) uygulamasının mutfak yönetimine etkileri üzerine sektörel bir araştırma. Master thesis, Akdeniz University, Antalya, Turkey.

Pırnar, İ. (2015). Yiyecek içecek işletmeleri yönetimi. (1. Edition). Ankara: Beta Basım Yayım Dağıtım.

Sanchez-Canizares, S. M., \& Lopez-Guzman, T. (2012). Gastronomy as a tourism resource: Profile of the culinary tourist. Current Issues in Tourism, 15(3), 229-245.

Shenoy, S. S. (2005). Food tourism and the culinary tourist. Doctorate dissertation, Clemson University, South Carolina, USA. 
Smith, S., \& Costello, C. (2008). Culinary tourism: Satisfaction with a culinary event utilizing importance-performance grid analysis. Journal of Vacation Marketing, 15(2), 99-110.

Şengül, S., \& Türkay, O. (2016). Yöresel mutfak unsurlarının turizm destinasyonu seçimindeki rolü (Mudurnu örneği). International Journal of Management Economicsand Business, 12(29), 63-87.

Tanrı̈ğen, A. (2014). Bilimsel araştırma yöntemleri. (4. Baskı). Ankara: Anı Yayıncılık.

Tekin, Ö. A., \& Çidem, G. (2015). Turizm öğrencilerinin mutfak departmanına yönelik tutumları ölçeği: Bir geçerlik ve güvenirlik çalışması. Uluslararası Sosyal Araştırmalar Dergisi, 8(39), 975-986.

Tekin, Ö. A., \& Çidem, G. (2017). Önlisans turizm öğrencilerinin mutfak departmanında kariyere yönelik tutumları: Süleyman Demirel Üniversitesi örneği. Dumlupınar Üniversitesi Sosyal Bilimler Dergisi, 52, 33-51.

Tekin, Ö. A., \& Deniz, İ. (2015). Turizm öğrencilerinin yiyecek ve içecek departmanına yönelik tutumları: Üniversite öğrencileri üzerine bir inceleme. Elektronik Sosyal Bilimler Dergisi,14(55), 178-197.

Tez, Z. (2018). Lezzetin tarihi, geçmişten bugüne yiyecek, içecek ve keyif vericiler.(4. Edition). İstanbul: Hayykitap.

Toksöz, D., \& Aras, S. (2016). Turistlerin seyahat motivasyonlarında yöresel mutfağın rolü. Journal of Tourism and Gastronomy Studies, 4: Special Issue 1, 174-189.

Tripodi, S. J., \& Bender, K. (2010). The handbook of social work research methods. in: Chapter 7: Descriptive Studies, (Ed. Bruce A. Thyer), California, USA: SAGE Publishing.

Ural, A., \& K1lıç, İ. (2011). Bilimsel araştırma süreci ve spss ile veri analizi. (3. Edition). Ankara: Detay Yayıncılık.

Yun, D., Hennessey, S. M. \& MacDonald, R. (2011). Understanding Culinary Tourists: Segmentations Based on Past Culinary Experiences and Attitudes Toward Food-Related Behavior. International CHRIE Conference-Refereed Track, 15, 1-13.

Zağralı, E., \& Akbaba, A. (2015). Turistlerin destinasyon seçiminde rol oynayan bir etken olarak yerel mutfaklar: İzmir yarımadası'nı ziyaret eden turistlerin algılamaları üzerine bir araştırma. Journal of Tourism Theory and Research, 1(2), 97-106. 